\title{
Genetically Diverse Peach Seedling Rootstocks Affect Long-term Performance of 'Redhaven' Peach on Fox Sand
}

\author{
Richard E.C. Layne \\ Agriculture Canada, Research Station, Harrow, Ontario NOR 1G0, Canada \\ Perry Y. Jui \\ Agriculture Canada, Research Branch, Eastern Region, Ottawa, Ontario K1A 0C6, Canada \\ Additional index words. Prunus persica, Leucostoma spp., cold hardiness, trunk cross-sectional area, TCA, yield, yield \\ efficiency, survival
}

\begin{abstract}
Ten genetically diverse peach [Prunus persica (L.) Batsch] seedling rootstocks were studied for 10 years on Fox sand using 'Redhaven' as the scion. The purpose of the experiment was to assess the performance of three Harrow Research Station (Ont.) hybrid selections (H7338013, H7338016, and H7338019) and two northern China introductions ('Chui Lum Tao' and 'Tzim Pee Tao') against five commercial standards, two of which were selected in Canada ('Harrow Blood' and 'Siberian C') and three in the United States ('Bailey', 'Halford', and 'Lovell'). Rootstock performance was assessed indirectly by measuring or subjectively rating various aspects of scion performance including annual trunk crosssectional area (TCA); final tree height, spread, and TCA; bloom and fruit set intensity; yield and yield efficiency; canker (Leucostoma spp.) severity; defoliation rate; winter injury; cold hardiness of flower buds and shoot xylem; and tree survival. Rootstock effects on the above measurements and ratings were significant in some years and not in others. Year effects were always large and significant, while rootstock $\times$ year interactions were usually small and not significant. In the combined analyses over years, the largest rootstock effects were obtained for bloom, fruit set, and defoliation ratings and for TCA measurements. Three cumulative responses, including marketable yields, yield efficiency, and tree survival, were used for comparing the five experimental rootstocks with the five commercial standards and also for ranking the 10 rootstocks with respect to each other to assess their potential commercial value as peach rootstocks. 'Chui Lum Tao', H7338013, and 'Bailey' had the most commercial potential for southern Ontario because they typically promoted above average cumulative yield, yield efficiency, and tree survival. 'Tzim Pee Tao', 'Siberian C', and 'Harrow Blood' were less valuable, with low cumulative marketable yields. 'Halford' and 'Lovell' were the least valuable, with the lowest tree survival (17\%). Performance of $\mathbf{H 7 3 3 8 0 1 3}$ exceeded that of both parents ('Bailey' and 'Siberian C'), $\mathbf{H 7 3 3 8 0 1 9}$ exceeded 'Siberian C' but not 'Bailey', while performance of $\mathbf{H 7 3 3 8 0 1 6}$ was inferior to both parents. Wider testing of the experimental rootstocks on different soil types and climatic zones is needed.
\end{abstract}

Peach seedlings are the principal rootstocks used for peach and nectarine worldwide (Layne, 1987b). They comprise three groups: 1) wild types, 2) seeds from commercial cultivars used primarily in processing and drying industries, and 3 ) those especially bred or selected for use as rootstock seed sources. The first group represents peaches that have escaped cultivation and are found growing in a wild or nearly wild state such as the Tennessee naturals and Indian peaches of North America (Layne, 1987b). A major problem with these seed sources is their genetic variability and lack of uniformity in the nursery and the orchard (Rom, 1983). The second group, consisting of seeds from commercial varieties, is more genetically uniform in the nursery and orchard than the first group and performance is more predictable (Layne, 1987b). Examples of the second group are 'Halford' and 'Lovell', which originated in California as canning and drying cultivars, respectively, and are important peach rootstocks in Canada, the United States, and Mexico (Elfving and Tehrani, 1984; Layne, 1987b). The third group consists of cultivars that have little or no commercial value other than as rootstock seed sources for peach and nectarine. Examples of this group include 'Siberian C' and 'Harrow Blood', selected in Canada at the Harrow Research Station (Ont.); 'Bailey', selected in Iowa; and GF305 and 'Rubira', selected in France

Received for publication 9 Feb. 1994. Accepted for publication 31 May 1994. We gratefully acknowledge the technical assistance of M. Gadsby, H.O. Jackson, E.W. Lamoure, M.D. St. Pierre, and F.D. Stroud. The cost of publishing this paper was defrayed in part by the payment of page charges. Under postal regulations, this paper therefore must be hereby marked advertisement solely to indicate this fact.
(Beckman and Cummins, 1992; Layne, 1987b).

A common feature of peach seedling rootstocks is their generally good compatibility with a broad range of peach and nectarine scion cultivars and good adaptation to well-drained sands, sandy loams, gravelly loam, and silt loam soil types (Layne, 1987b). These features account for their widespread and general use in all peach-producing regions of the world (Layne, 1987b; Rom, 1983).

In 1971, a rootstock breeding program was initiated at the Harrow Research Station to improve cold hardiness and rootlesion nematode (Pratylenchus penetrans Cobb) resistance of peach seedling rootstocks (Layne, 1987a, 1987b; 1989a, 1989b; Potter et al., 1984). In 1979, three Harrow 'Bailey' x 'Siberian C' hybrids (H7338013, H7338016, and H7338019) were selected based on tree type, cold hardiness, canker resistance, and productivity (R.E.C. Layne, unpublished data). Open-pollinated seeds from these and other selections were subsequently tested for germination, uniformity in the nursery, freedom from suckering (R.E.C. Layne, unpublished data), and resistance to root-lesion nematode (Potter et al., 1984). Open-pollinated seeds from $\mathrm{H} 7338013, \mathrm{H} 7338016$, and $\mathrm{H} 7338019$ were used to compare these seed sources in advanced trials in a replicated orchard experiment with open-pollinated seeds of five commercial standards: 'Bailey', 'Halford', 'Harrow Blood', 'Lovell', and 'Siberian C' (Elfving and Tehrani, 1984; Layne, 1987b). In addition, two cold-hardy introductions from northern China ('Chui Lum Tao' and 'Tzim Pee Tao') (Layne, 1987b, 1989b) were also included in the experiment because they had not yet been tested as potential peach rootstocks in Canada. 'Redhaven' was chosen as the common 
scion for the 10 rootstocks because of its importance as a cultivar in Ontario and many other peach-producing regions of the world. Preliminary reports of this work have been made (Layne, 1987a, 1987b; 1989a, 1989b).

\section{Materials and Methods}

The experimental orchard was established in 1982 on a Fox sand soil series at the Harrow Research Station Ridge Farm $\left(\approx 42^{\circ} \mathrm{N}, \approx 82^{\circ} 54^{\prime} \mathrm{W}\right)$. For all rootstocks, 1-year-old 'Redhaven' budded nursery trees were used and planted with the bud union just above the soil surface to prevent scion rooting. The rootstock seed sources were derived from open pollination of the following selffertile clones: 'Bailey', 'Chui Lum Tao', 'Halford', 'Harrow Blood', 'Lovell', 'Siberian C', 'Tzim Pee Tao', H7338013, H7338016, and H7338019. The soil type has been previously described (Layne et al., 1986). The orchard site was fumigated in the fall before planting with the nematicide 1,2-dichloropropane with 1,3-dichloropropene ('D-D') at 337 liters $\cdot$ ha $^{-1}$ to control rootlesion nematodes, the major nematode peach pest in Ontario (Potter et al., 1984).

The experimental design was a randomized complete block with six replications. Each row of experimental trees was a replication and consisted of single-tree plots of each of the 10 scion-rootstock combinations. Trees were spaced $6.0 \times 6.0 \mathrm{~m}$ to provide a tree density of 278 trees/ha. A guard row of 'Redhaven' on a random assortment of peach seedling rootstocks surrounded the experimental orchard and also separated each of the six rows of experimental trees.

The orchard was managed according to local recommendations for Ontario peach growers (Ontario Ministry of Agriculture and Food, 1991). Row middles were cultivated from April to the end of June, then a cover crop of Italian ryegrass (Lolium multiflorum Lam.) was sown the first week of July. Weeds in the tree row were controlled with two or more seasonal applications of 1,1'-dimethyl-4,4'-bipyridinium ion (paraquat). Each year, $190.5 \mathrm{~kg}$ of $0 \mathrm{~N}-$ $10 \mathrm{P}_{2} \mathrm{O}_{5}-30 \mathrm{~K}_{2} \mathrm{O}$ (percent) fertilizer per hectare was broadcast in the spring. Beginning in 1983, banded applications of $\mathrm{NH}_{4} \mathrm{NO}_{3}$ (34-0-0) were made annually in April at the drip line of each tree. The rate of $\mathrm{N}$ was $0.02 \mathrm{~kg} /$ tree in 1983 and was increased by 0.02 $\mathrm{kg} /$ tree per year from 1983 to 1991 .

In the fall each year, growth measurements were recorded as trunk circumference $30 \mathrm{~cm}$ above the soil surface and converted to trunk cross-sectional area (TCA). In the tenth year, the height and spread of each tree was recorded. Each year, the same observer rated subjectively winter injury, canker (Leucostoma spp.), bloom intensity, fruit set after June drop, and defoliation rate. A 1 to 10 rating scale (Table 1 ) was used where $1=$ the poorest possible rating and $10=$ the best possible for each of the following ratings: winter injury, canker, bloom intensity, and fruit set. Defoliation ratings were estimated in 10 equal percentiles (Table 1). Trees were defruited in the second season to promote vegetative growth. In the third season, fruit were spaced $30 \mathrm{~cm}$ apart to encourage tree growth, but in the fourth and subsequent seasons, they were spaced $15 \mathrm{~cm}$ apart. Only trees with fruit set ratings of 6 or higher (Table 1) required hand thinning. Yields were recorded annually from years 3 to 10 (1984 to 1991). A 7-kg fruit sample per tree was taken, usually from the second harvest, and graded into each of three size classes arbitrarily designated as large $(>64 \mathrm{~mm})$, medium ( $<64$ to $>54 \mathrm{~mm})$, and small $(<54 \mathrm{~mm})$. Split pits were treated as a separate

Table 1. A subjective, numeric rating scale for five aspects of 'Redhaven' performance.

\begin{tabular}{|c|c|c|c|c|c|}
\hline \multirow[b]{2}{*}{$\begin{array}{l}\text { Numeric } \\
\text { scale }\end{array}$} & \multicolumn{5}{|c|}{ Description of numeric ratings by characters rated } \\
\hline & $\begin{array}{l}\text { Winter } \\
\text { injury }\end{array}$ & $\begin{array}{c}\text { Canker } \\
\text { (Leucostoma } \text { spp.) }\end{array}$ & Bloom & $\begin{array}{c}\text { Fruit } \\
\text { set }\end{array}$ & $\begin{array}{l}\text { Defoliation } \\
\quad(\%)\end{array}$ \\
\hline$\overline{1}$ & Severe, tree dead & Severe, tree dead & None & None & $>0$ to 10 \\
\hline 2 & Severe, tree dying & Severe, tree dying & Trace & Trace & $>10$ to 20 \\
\hline \multirow[t]{2}{*}{3} & Two major scaffold branches dead & $\begin{array}{l}\text { Severe in each of trunk, } \\
\text { crotches and lower }\end{array}$ & & & \\
\hline & & scaffold branches & Very light & Very light & $>20$ to 30 \\
\hline \multirow[t]{2}{*}{4} & One major scaffold branch dead & $\begin{array}{l}\text { Severe in two of trunk, } \\
\text { crotches or lower }\end{array}$ & & & \\
\hline & & scaffold branches & Light & Light & $>30$ to 40 \\
\hline \multirow[t]{2}{*}{5} & Secondary and tertiary branches dead & $\begin{array}{l}\text { Severe in one of trunk, } \\
\text { crotches or lower }\end{array}$ & & & \\
\hline & & scaffold branches & Light to medium & Light to medium & $>40$ to 50 \\
\hline \multirow[t]{2}{*}{6} & Tertiary branches dead & $\begin{array}{l}\text { Moderate in trunk, } \\
\text { crotches and lower } \\
\text { scaffold branches }\end{array}$ & & & \\
\hline & & but severe in smaller branches & Medium & Medium & $>50$ to 60 \\
\hline \multirow[t]{2}{*}{7} & 1- and 2-year-old shoots dead & $\begin{array}{l}\text { Light to moderate in trunk, } \\
\text { crotches and lower } \\
\text { scaffold branches, } \\
\text { moderate to severe in }\end{array}$ & & & \\
\hline & & smaller branches & Medium to heavy & Medium to heavy & $>60$ to 70 \\
\hline 8 & 1-year-old shoots dead & $\begin{array}{l}\text { Very light in major } \\
\text { framework of tree, } \\
\text { light elsewhere }\end{array}$ & Heavy & Heavy & $>70$ to 80 \\
\hline 9 & Tips of 1-year-old shoots dead & $\begin{array}{l}\text { Confined to one and } \\
\text { two year old shoots }\end{array}$ & Very heavy & Very heavy & $>80$ to 90 \\
\hline 10 & None observed & None observed & Profuse & Profuse & $>90$ to 100 \\
\hline
\end{tabular}


class and weighed separately. Total yield comprised the combined weight of all fruit harvested in a season before grading. Marketable yield excluded the proportion of the total yield attributed to split pits and small fruit. As trees died in the experimental or guard rows, they were replaced with 'Redhaven'/Siberian C nursery trees to maintain the same tree density, but no data were recorded on replacement trees.

To assess the influence of rootstock on 'Redhaven' scion cold hardiness, controlled freezing tests were conducted on preconditioned dormant shoots in 1985, 1988, 1989, and 1990. The shoots collected for freezing trials each year included the annual increment of shoot growth made during the previous year's growing season.

On 23 Jan. 1985, dormant shoots (20 per tree per replication) were collected and preconditioned by holding for 8 days at $-10 \mathrm{C}$ in plastic bags. They were then subjected to a controlled freezing test on 31 Jan. 1985 at a cooling rate of 5C/h. Samples were removed as soon as $-28,-30$, and $-32 \mathrm{C}$ were attained to assess freezing injury at those temperatures. Following the freezing tests, all shoots were triple-bagged in plastic bags and held at $-3 \mathrm{C}$ for 24 h, $3 \mathrm{C}$ for 3 days, then room temperature $(\approx 23 \mathrm{C})$ for $24 \mathrm{~h}$ before flower bud and shoot xylem injury were assessed. The temperature required to kill $50 \%\left(\mathrm{~T}_{50}\right)$ of flower buds and shoot xylem of acclimated shoots was determined (Layne, 1989c, 1992). Similar samples were collected on 9 Feb. 1988 from outdoors, preconditioned as before, subjected to controlled freezing on 18 Feb. 1988, and assessed for injury on 14 Mar. 1988. The $\mathrm{T}_{50}$ values were determined as before for flower buds and shoot xylem.

On 19 Dec. 1988 and 1989, similar samples of dormant shoots were collected and preconditioned by holding samples at $-3 \mathrm{C}$ for 21 days, at $-5 \mathrm{C}$ for 7 days, and then at $-10 \mathrm{C}$ for 7 days to induce maximum hardiness. The shoots were then subjected to standard controlled freezing tests on 24 Jan. 1989 and 25 Jan. 1990 (Layne $1989 \mathrm{c}, 1992) . \mathrm{T}_{50}$ values for flower bud and shoot xylem injury were obtained as before.

The data within years from this experiment were analyzed by analysis of variance (ANOVA) for a randomized complete-block design. The data over years were analyzed by using repeated measures analysis treating year as a split-plot (PROG GLM, SAS
Institute, Cary, N.C.). The total and marketable yields, which are likely to be affected by tree size were analyzed using TCA as the covariate. The relationships among dormancy, survival, and hardiness variables were established based on the correlations among canker, winter injury, defoliation, bud hardiness, and xylem hardiness. Similarly, the relationships among growth and yield variables were examined through the correlations among total yield, yield of large fruit, bloom, fruit set, TCA, and cropping efficiency. Duncan's multiple range test was used to compare rootstock means.

\section{Results}

Natural winter injury. Winter injury ratings increased in severity with tree age regardless of rootstock effects (data not presented). In 5 of the 9 years, rootstocks differed significantly with respect to winter injury of 'Redhaven' scions, while in the other 4 years they did not. In the combined analysis of 9 years of winter injury data, there was neither a rootstock effect nor a rootstock $\times$ year interaction, but there was a large year effect $(P<0.001)$.

Controlled freezing. In 2 (1985 and 1989) of the 4 years, flower bud hardiness was significantly influenced by rootstock, while in the other 2 years (1989 and 1990) it was not (Table 2). 'Bailey' and 'Harrow Blood' were associated with the hardiest flower buds in 1985 when buds were preconditioned for 8 days, 'Halford' was associated with the least hardy buds, and the remaining rootstocks had an intermediate but similar effect. In 1988, 'Siberian C' was associated with the hardiest buds and H7338019 with the least hardy. The combined analysis of bud hardiness data for the 4 years indicated neither a significant rootstock effect nor a rootstock $x$ year interaction on bud hardiness, but there was a large year effect $(P<0.001)$.

Shoot xylem hardiness in 1985 and 1989 was influenced by rootstock (Table 3). In 1985, 'Tzim Pee Tao' was associated with the hardiest and H7338016 with the least hardy xylem, while in 1989 'Harrow Blood' and H7338013 were associated with the hardiest and H7338019 with the least hardy xylem. The combined analysis of xylem hardiness data for the 4 years indicated neither a significant rootstock effect nor a rootstock $\times$ year interaction on

Table 2. Cold hardiness of 'Redhaven' peach flower buds on 10 peach seedling roostocks.

\begin{tabular}{|c|c|c|c|c|}
\hline \multirow[b]{3}{*}{ Rootstock } & \multicolumn{4}{|c|}{$\mathrm{T}_{50}$ flower buds $\left({ }^{\circ} \mathrm{C}\right)^{\mathrm{Z}}$} \\
\hline & \multicolumn{2}{|c|}{$\begin{array}{l}\text { Dormant shoots } \\
\text { preconditioned } \\
\text { for } 8 \text { days }^{y}\end{array}$} & \multicolumn{2}{|c|}{$\begin{array}{c}\text { Dormant shoots } \\
\text { preconditioned } \\
\text { for } 35 \text { days }^{\mathrm{x}}\end{array}$} \\
\hline & 1985 & 1988 & 1989 & 1990 \\
\hline$\overline{\text { Bailey }}$ & $-27.1 \mathrm{a}^{\mathrm{w}}$ & $-22.0 \mathrm{bc}$ & $-25.3 \mathrm{a}$ & $\overline{-26.1 \mathrm{a}}$ \\
\hline Chui Lum Tao & $-26.8 \mathrm{ab}$ & $-22.6 b c$ & $-25.7 \mathrm{a}$ & $-26.1 \mathrm{a}$ \\
\hline Halford & $-26.6 b$ & $-22.1 b c$ & $-25.6 \mathrm{a}$ & $-26.0 \mathrm{a}$ \\
\hline Harrow Blood & $-27.1 \mathrm{a}$ & $-21.9 b c$ & $-25.7 \mathrm{a}$ & $-26.1 \mathrm{a}$ \\
\hline Lovell & $-26.9 \mathrm{ab}$ & $-22.6 b$ & $-25.7 \mathrm{a}$ & $-26.3 \mathrm{a}$ \\
\hline Siberian C & $-26.7 \mathrm{ab}$ & $-23.4 \mathrm{a}$ & $-25.3 \mathrm{a}$ & $-26.6 \mathrm{a}$ \\
\hline Tzim Pee Tao & $-26.9 \mathrm{ab}$ & $-22.4 b c$ & $-25.8 \mathrm{a}$ & $-26.5 \mathrm{a}$ \\
\hline H7338013 & $-26.9 \mathrm{ab}$ & $-22.2 b c$ & $-26.0 \mathrm{a}$ & $-26.0 \mathrm{a}$ \\
\hline H7338016 & $-26.9 \mathrm{ab}$ & $-22.2 b c$ & $-25.9 \mathrm{a}$ & $-26.3 \mathrm{a}$ \\
\hline H7338019 & $-26.8 \mathrm{ab}$ & $-21.8 \mathrm{c}$ & $-25.7 \mathrm{a}$ & $-26.5 \mathrm{a}$ \\
\hline
\end{tabular}

${ }^{\mathrm{z}} \mathrm{T}_{50}=$ temperature required to kill $50 \%$ of the flower buds.

${ }^{\mathrm{y}}$ Shoots were collected from outdoors in January or February and held at $-10 \mathrm{C}$ for 8 days before controlled freezing tests were conducted. ${ }^{\mathrm{x}}$ Shoots were collected in December and held at $-3 \mathrm{C}$ for 21 days, $-5 \mathrm{C}$ for 7 days, and $-10 \mathrm{C}$ for 7 days before controlled freezing tests were conducted.

${ }^{\text {w} M e a n ~ s e p a r a t i o n ~ o f ~ r o o t s t o c k s ~ i n ~ c o l u m n s ~ a c c o r d i n g ~ t o ~ D u n c a n ' s ~ m u l t i p l e ~ r a n g e ~ t e s t ~}(P<0.05)$. 
Table 3. Cold hardiness of 'Redhaven' peach shoot xylem on 10 peach seedling rootstocks.

\begin{tabular}{|c|c|c|c|c|}
\hline \multirow[b]{3}{*}{ Rootstock } & \multicolumn{4}{|c|}{$\mathrm{T}_{50}$ shoot xylem $\left({ }^{\circ} \mathrm{C}\right)^{\mathrm{z}}$} \\
\hline & \multicolumn{2}{|c|}{$\begin{array}{l}\text { Dormant shoots } \\
\text { preconditioned } \\
\text { for } 8 \text { days }^{y}\end{array}$} & \multicolumn{2}{|c|}{$\begin{array}{l}\text { Dormant shoots } \\
\text { preconditioned } \\
\text { for } 35 \text { days }^{\mathrm{x}}\end{array}$} \\
\hline & 1985 & 1988 & 1989 & 1990 \\
\hline Bailey & $-29.9 a b^{w}$ & $-27.1 \mathrm{a}$ & $-29.0 \mathrm{ab}$ & $-32.2 \mathrm{a}$ \\
\hline Chui Lum Tao & $-29.6 \mathrm{ab}$ & $-27.3 \mathrm{a}$ & $-28.9 a b$ & $-32.3 \mathrm{a}$ \\
\hline Halford & $-29.6 \mathrm{ab}$ & $-27.3 \mathrm{a}$ & $-28.6 a b$ & $-31.8 \mathrm{a}$ \\
\hline Harrow Blood & $-30.0 \mathrm{ab}$ & $-27.1 \mathrm{a}$ & $-29.3 \mathrm{a}$ & $-32.0 \mathrm{a}$ \\
\hline Lovell & $-29.6 \mathrm{ab}$ & $-27.3 \mathrm{a}$ & $-28.9 \mathrm{ab}$ & $-31.7 \mathrm{a}$ \\
\hline Siberian C & $-29.7 \mathrm{ab}$ & $-27.7 \mathrm{a}$ & $-28.9 a b$ & $-32.4 \mathrm{a}$ \\
\hline Tzim Pee Tao & $-30.1 \mathrm{a}$ & $-27.4 \mathrm{a}$ & $-29.1 \mathrm{ab}$ & $-32.4 \mathrm{a}$ \\
\hline H7338013 & $-29.7 \mathrm{ab}$ & $-26.9 \mathrm{a}$ & $-29.3 \mathrm{a}$ & $-32.1 \mathrm{a}$ \\
\hline H7338016 & $-29.5 \mathrm{~b}$ & $-27.6 \mathrm{a}$ & $-28.9 a b$ & $-32.2 \mathrm{a}$ \\
\hline H7338019 & $-29.8 \mathrm{ab}$ & $-27.6 \mathrm{a}$ & $-28.1 \mathrm{~b}$ & $-31.9 \mathrm{a}$ \\
\hline
\end{tabular}

${ }^{\mathrm{z}} \mathrm{T}_{50}=$ temperature required to kill $50 \%$ of the shoot xylem.

y Dormant shoots were collected from outdoors in January or February and held at $-10 \mathrm{C}$ before controlled freezing tests were conducted.

${ }^{\mathrm{x}}$ Dormant shoots were collected in December and held at $-3 \mathrm{C}$ for 21 days, $-5 \mathrm{C}$ for 7 days, and $-10 \mathrm{C}$ for 7 days before controlled freezing tests were conducted.

${ }^{\text {w} M e a n ~ s e p a r a t i o n ~ o f ~ r o o t s t o c k s ~ i n ~ c o l u m n s ~ a c c o r d i n g ~ t o ~ D u n c a n ' s ~ m u l t i p l e ~ r a n g e ~ t e s t ~}(P<0.05)$.

xylem hardiness, but there was a large year effect $(P<0.001)$.

Canker rating. Canker incidence and severity increased progressively from the second to the tenth year of orchard life (data not presented). All trees were canker-free in the second (1983) and heavily cankered by the tenth year (1991), regardless of rootstock. In the analysis of 9 years of canker data, neither the rootstock effect nor the rootstock $\times$ year interaction was significant, but there was a large year effect $(P<0.001)$.

Defoliation rating. In 5 of the 8 years during which defoliation data were obtained, rootstock influenced scion defoliation ratings, while in the other 3 years it did not (data not presented). In the combined analysis of 8 years of defoliation data, there was a significant rootstock effect $(P<0.001)$ on scion defoliation rating, a significant rootstock $\times$ year interaction $(P<0.001)$, and a large year effect $(P<0.001)$. Defoliation rating was lower on 'Harrow Blood' and 'Halford' than on the other rootstocks, and was usually highest on 'Siberian C'.

Tree size in the tenth year. Tree height, spread, and TCA all varied significantly with respect to rootstock (Table 4) in the tenth and final year of the experiment. The tallest trees were on 'Halford' and the shortest were on 'Siberian C'. The widest trees were on 'Halford' and H7338019 and the narrowest were on 'Siberian C'. Trees with the largest TCA were on 'Halford' and those with the smallest were on 'Siberian C'. The combined analysis of 8 years of TCA measurements indicated that there was a significant rootstock effect on TCA $(P<0.001)$, a significant rootstock $\times$ year interaction $(P<0.001)$, and a large year effect $(P<0.001)$. Average TCA was greatest but similar on H7338013, 'Chui Lum Tao', and H7338016; smallest on 'Siberian C'; and intermediate on the remaining rootstocks.

Bloom rating. In 5 of the 9 years, rootstocks differed significantly from each other for bloom ratings, but in the other 4 years bloom ratings were similar, regardless of rootstock (data not presented). Bloom was heaviest on 'Tzim Pee Tao' and lightest on 'Harrow Blood'. In the analysis of the 9 years of bloom data, there was a small but significant rootstock effect on bloom ratings $(P<$ $0.05)$, a large year effect $(P<0.001)$, but no rootstock $\times$ year interaction.

Fruit set rating. In each year except 1988, fruit set ratings were high enough ( $>5.0)$ to anticipate a full commercial crop (data not
Table 4. Tree height, spread, and trunk cross-sectional area (TCA) of 'Redhaven' peach in the tenth year (1991) on 10 peach seedling rootstocks.

\begin{tabular}{llll}
\hline \hline Rootstock & $\begin{array}{c}\text { Tree ht } \\
(\mathrm{m})\end{array}$ & $\begin{array}{c}\text { Tree spread } \\
(\mathrm{m})\end{array}$ & $\begin{array}{c}\text { TCA } \\
\left(\mathrm{cm}^{2}\right)\end{array}$ \\
\hline Bailey & $3.25 \mathrm{bcd}^{\mathrm{z}}$ & $4.95 \mathrm{ab}$ & $184.6 \mathrm{c}$ \\
Chui Lum Tao & $3.30 \mathrm{bcd}$ & $5.67 \mathrm{ab}$ & $209.1 \mathrm{bc}$ \\
Halford & $4.06 \mathrm{a}$ & $6.01 \mathrm{a}$ & $322.9 \mathrm{a}$ \\
Harrow Blood & $3.40 \mathrm{bcd}$ & $5.33 \mathrm{ab}$ & $184.3 \mathrm{c}$ \\
Lovell & $3.00 \mathrm{~cd}$ & $5.89 \mathrm{ab}$ & $172.8 \mathrm{c}$ \\
Siberian C & $2.83 \mathrm{~d}$ & $3.92 \mathrm{~b}$ & $106.4 \mathrm{~d}$ \\
Tzim Pee Tao & $3.50 \mathrm{abc}$ & $5.12 \mathrm{ab}$ & $209.0 \mathrm{bc}$ \\
H7338013 & $3.54 \mathrm{abc}$ & $5.34 \mathrm{ab}$ & $221.8 \mathrm{bc}$ \\
H7338016 & $3.50 \mathrm{abc}$ & $5.08 \mathrm{ab}$ & $220.7 \mathrm{bc}$ \\
H7338019 & $3.85 \mathrm{ab}$ & $6.06 \mathrm{a}$ & $256.4 \mathrm{~b}$
\end{tabular}

$\overline{{ }^{z} \text { Mean separation of rootstocks within columns according to Duncan's }}$ multiple range test $(P<0.05)$.

presented). Rootstocks differed significantly in fruit set ratings only in the seventh (1988), eighth (1989), and tenth (1991) years. In the analysis of 8 years of data, there was a small but significant rootstock effect on fruit set rating $(P<0.05)$, a large year effect $(P$ $<0.01)$, and no rootstock $\times$ year interaction. The average response indicated that fruit set was typically highest on H7338013 and 'Chui Lum Tao' and lowest on 'Lovell' and 'Halford', while the remaining rootstocks were intermediate in effect.

Yield. The general pattern of total yield over the 8 cropping years is summarized in Fig. 1. Yields increased sharply in the first 3 cropping years, regardless of rootstock. They reached a plateau or declined slightly in the next 3 cropping years, increased in the seventh, and then decreased in the eighth cropping year. In the early years, yields were highest on 'Chui Lum Tao' and remained comparatively high on 'Chui Lum Tao' compared with most other rootstocks. Some rootstocks, such as 'Siberian C', promoted relatively high yields for the first 5 cropping years, then yields declined faster on this rootstock than the others in the last 3 years. Other rootstocks, like 'Halford', promoted relatively low to medium yields during the first 6 cropping years, but were the highest yielding in the seventh and eighth year. For the total yield based on 


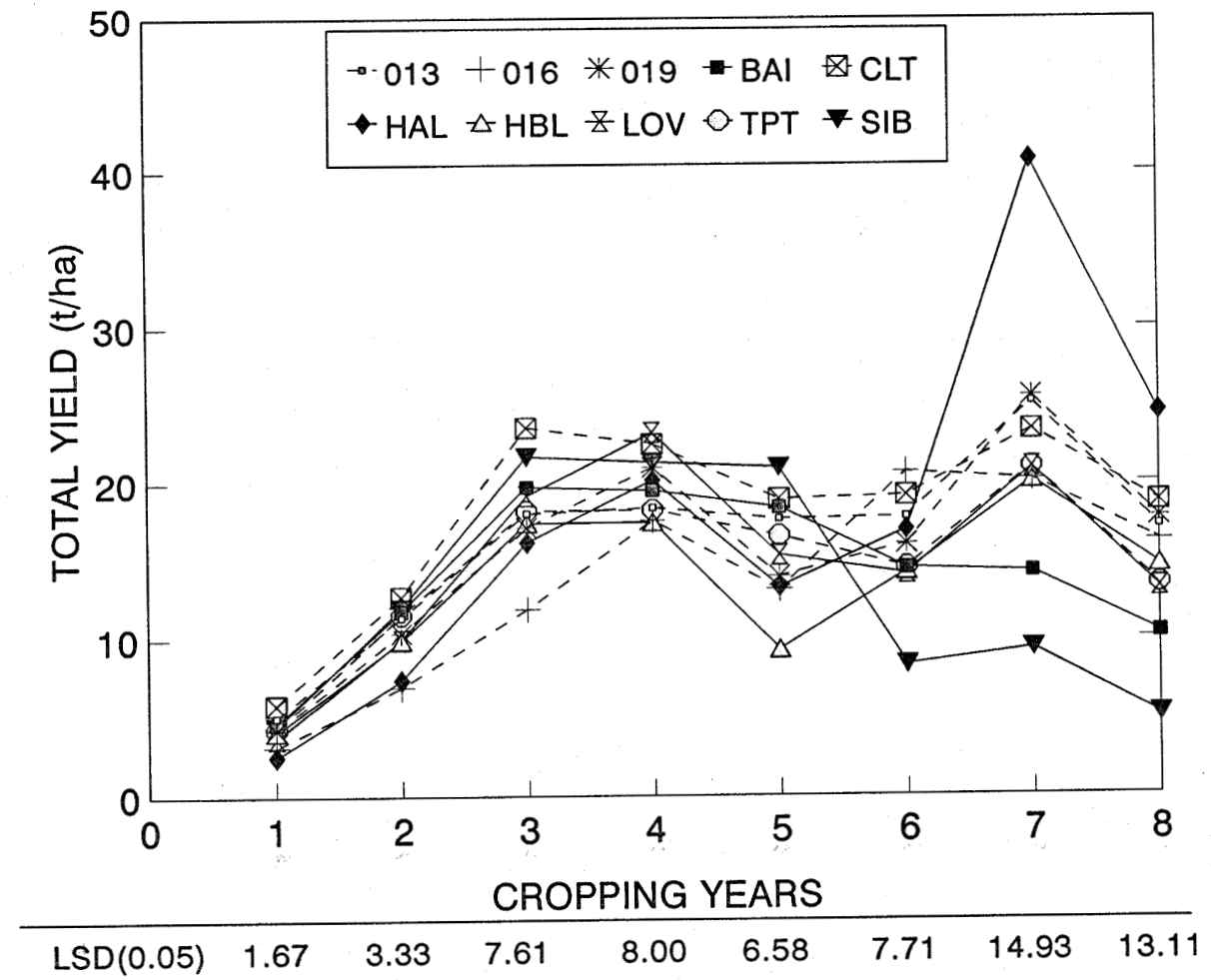

Fig. 1. Rootstock influence on estimated total yield of 'Redhaven' peach from the first (1984) to the eighth (1991) cropping year. Estimated yield calculated from individual tree yields $\times 278$ trees/ha. LSD (0.05) for rootstock means based on data from each cropping year. $013=\mathrm{H} 7338013,016=\mathrm{H7338016,019}=\mathrm{H7338019}$, BAI = 'Bailey', CLT = 'Chui Lum Tao', HAL = 'Halford', HBL = 'Harrow Blood', LOV = 'Lovell', TPT = 'Tzim Pee Tao', SIB = 'Siberian C'.

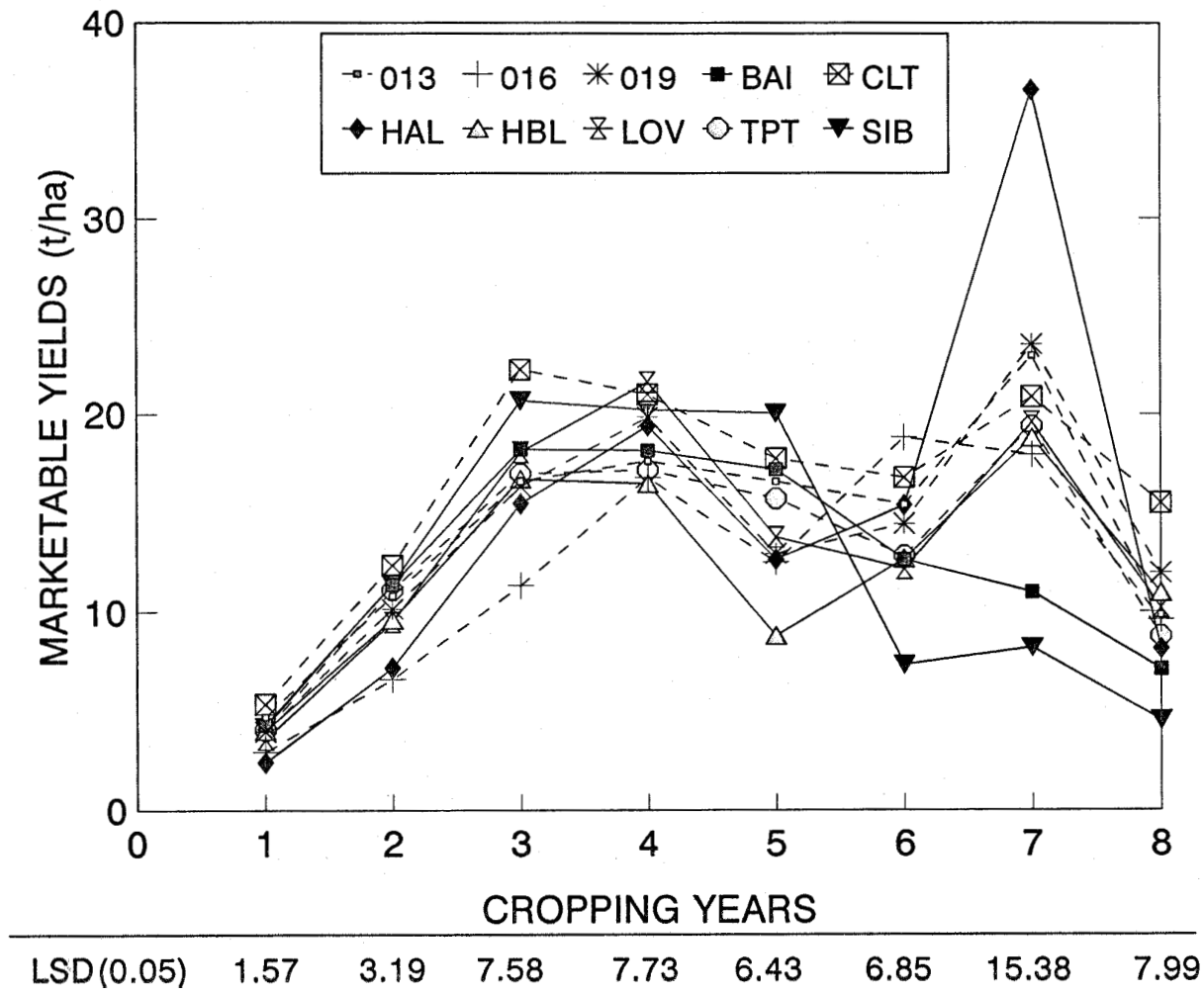

Fig. 2. Rootstock influence on estimated total yield of 'Redhaven' peach from the first (1984) to the eighth (1991) cropping year. Estimated yield calculated from individual tree yields $\times 278$ trees/ha. LSD (0.05) for rootstock means based on data from each cropping year. $013=\mathrm{H} 7338013,016=\mathrm{H7338016,019}=\mathrm{H7338019}$, BAI = 'Bailey', $\mathrm{CLT}=$ 'Chui Lum Tao', HAL = 'Halford', HBL = 'Harrow Blood', LOV = 'Lovell', TPT = 'Tzim Pee Tao', SIB = 'Siberian C'.

8 years of data, there was no rootstock effect and no rootstock $x$ year interaction, but there was a large year effect $(P<0.001)$. The average response over the 8 years indicated that yields before grading were highest on 'Chui Lum Tao' and lowest on 'Harrow Blood', while the remaining rootstocks were intermediate and similar. 


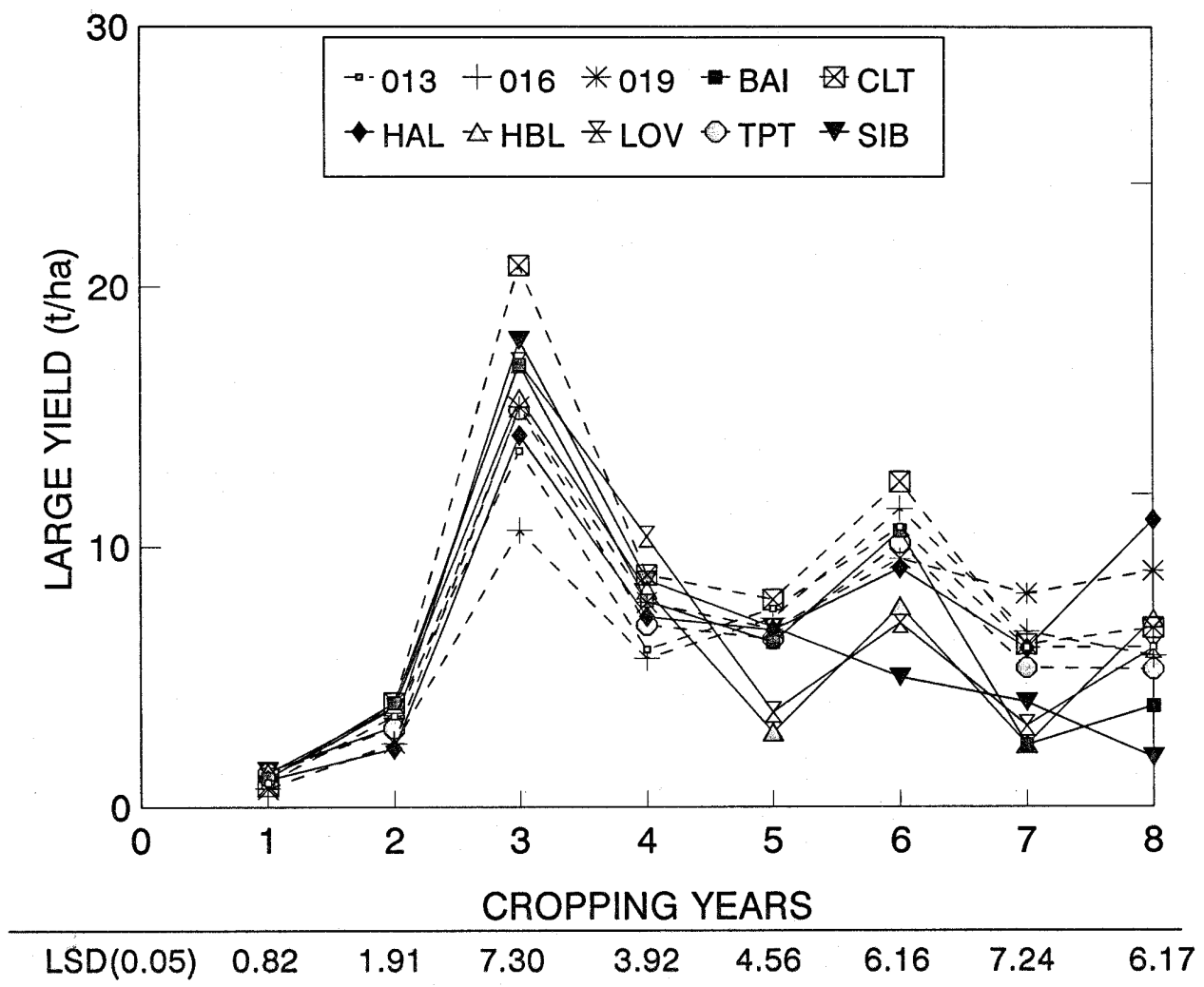

Fig. 3. Rootstock influence on estimated yield of large (>64 mm) fruit of 'Redhaven' peach from the first (1984) to the eighth (1991) cropping year. Estimated yield calculated from individual tree yields $\times 278$ trees/ha. LSD $(0.05)$ for rootstock means based on data from each cropping year. $013=\mathrm{H} 7338013,016=\mathrm{H} 7338016,019$ $=\mathrm{H7338019}, \mathrm{BAI}=$ 'Bailey', CLT $=$ 'Chui Lum Tao', HAL = 'Halford', HBL = 'Harrow Blood', LOV = 'Lovell', TPT = 'Tzim Pee Tao', SIB = 'Siberian C'.

Table 5. Mean total and marketable yield ${ }^{\mathrm{z}}$ of 'Redhaven' in the first 8 years of cropping and analysis of variance (ANOVA) using trunk crosssectional area (TCA) as the covariate.

\begin{tabular}{|c|c|c|c|}
\hline Rootstock & & $\begin{array}{c}\text { Total yield } \\
(\mathrm{kg} / \mathrm{tree})\end{array}$ & $\begin{array}{c}\text { Marketable yield } \\
(\mathrm{kg} / \text { tree })\end{array}$ \\
\hline Bailey & & 51.0 & 43.3 \\
\hline Chui Lum Tao & & 62.4 & 57.2 \\
\hline Halford & & 45.6 & 42.4 \\
\hline Harrow Blood & & 42.4 & 41.0 \\
\hline Lovell & & 45.2 & 41.6 \\
\hline Siberian C & & 48.0 & 44.1 \\
\hline Tzim Pee Tao & & 50.6 & 46.9 \\
\hline H7338013 & & 55.1 & 50.2 \\
\hline H7338016 & & 53.6 & 45.6 \\
\hline H7338019 & & 50.6 & 46.6 \\
\hline ANOVA & df & \multicolumn{2}{|c|}{ F test } \\
\hline Rootstock & 9 & $0.86^{\mathrm{NS}}$ & $0.88^{\mathrm{NS}}$ \\
\hline TCA & 1 & $21.40^{* * *}$ & $25.18^{* * * *}$ \\
\hline Replication & 49 & $1.30^{\mathrm{NS}}$ & $1.44^{*}$ \\
\hline Year & 6 & $30.85^{* * *}$ & $45.19^{* * * *}$ \\
\hline Rootstock $\times$ year & 53 & $0.91^{\mathrm{Ns}}$ & $0.93^{\mathrm{Ns}}$ \\
\hline
\end{tabular}

${ }^{\mathrm{z}}$ Obtained from individual tree yields.

Ns,*,**,**** Nonsignificant or significant at $P<0.05,0.01$, or 0.001 , respectively.

The general response in yield of marketable fruit (Fig. 2) was similar to that for total yield. Yields peaked in the third or fourth cropping year depending on rootstock, declined in the fifth and sixth, then either increased or decreased in the seventh depending on rootstock, but decreased on all rootstocks in the eighth cropping year. By the eighth cropping year, yields were generally similar to those obtained in the second year. The average yield of marketable fruit for the 8 cropping years was highest on 'Chui Lum Tao'; lowest but similar on 'Halford', 'Lovell', and 'Harrow Blood'; and intermediate but similar on the other rootstocks. The analysis of the 8 years of yield data indicated that neither the rootstock effect nor the rootstock $\times$ year interaction was significant; however, there was a large year effect $(P<0.001)$ on marketable yield.

There was a sharp increase in the yield of large $(>64 \mathrm{~mm})$ fruit in the first 3 cropping years regardless of rootstock, a sharp decline from the third to the fifth year (Fig. 3), but the response was inconsistent in subsequent years. The average yield over the 8 years was similar for all rootstocks. In the analysis of the large-fruit yield data, neither the rootstock nor the rootstock $\times$ year interaction was significant; however, the year effect was highly significant $(P$ $<0.001)$.

When total yields were adjusted for differences in TCA using ANOVA (Table 5), there was no rootstock effect on total yield. By contrast, there was a large TCA $(P<0.001)$ and year $(P<0.001)$ effect, but no rootstock $\times$ year interaction. When marketable yields were adjusted for differences in TCA, similar effects were obtained as noted for total yields.

Correlation. Correlation coefficients were calculated for dormancy and hardiness factors. Flower bud hardiness was positively and significantly correlated (Table 6) with shoot xylem hardiness, winter injury, and canker ratings but negatively correlated with late defoliation (low defoliation rating). The correlation between shoot xylem hardiness with the other variables was not significant. Winter injury ratings were positively correlated with canker but negatively correlated with late defoliation. Late defoliation was negatively correlated with canker ratings. 
Table 6. Correlation coefficients of bud hardiness, xylem hardiness, winter injury, defoliation, and canker (Leucostoma spp.) variables over rootstocks and years.

\begin{tabular}{lcccc}
\hline \hline Variables & Bud & Xylem & Winter & \\
correlated & $\mathrm{T}_{50}$ & $\mathrm{~T}_{50}$ & injury & Defoliation \\
\hline Xylem $\mathrm{T}_{50}$ & $0.67^{* * * *}$ & & & \\
Winter injury & $0.23^{* * * *}$ & $-0.02^{\mathrm{NS}}$ & & \\
Defoliation & $-0.56^{* * *}$ & $-0.10^{\mathrm{NS}}$ & $-0.45^{* * *}$ & \\
Canker & $0.21^{* *}$ & $0.09^{\mathrm{NS}}$ & $0.71^{* * *}$ & $-0.42^{* * *}$ \\
\hline Ns, ${ }^{*, * *, * * *}$ Nonsignificant or significant at $P<0.05,0.01$, or 0.001, respectively.
\end{tabular}

Table 7. Correlation coefficients of growth and yield variables over rootstocks and years.

\begin{tabular}{llcccc}
\hline \hline $\begin{array}{l}\text { Variables } \\
\text { correlated }\end{array}$ & $\begin{array}{c}\text { Bloom } \\
\text { rating }\end{array}$ & $\begin{array}{c}\text { Fruit } \\
\text { set }\end{array}$ & $\begin{array}{c}\text { Total } \\
\text { yield }\end{array}$ & $\begin{array}{c}\text { Large } \\
\text { yield }\end{array}$ & TCA $^{\mathrm{z}}$ \\
\hline Fruit set & $0.25^{* *}$ & & & & \\
Total yield & $0.37^{* * *}$ & $0.14^{*}$ & & & \\
Large yield & $0.05^{\mathrm{NS}}$ & $0.12^{*}$ & $0.68^{* * *}$ & & \\
TCA & $0.00^{\mathrm{NS}}$ & $-0.22^{* * *}$ & $0.61^{* * *}$ & $0.25^{* * *}$ & \\
Yield efficiency & $0.01^{\mathrm{NS}}$ & $0.07^{\mathrm{NS}}$ & $0.60^{* * *}$ & $0.40^{* * *}$ & $-0.11^{\mathrm{NS}}$
\end{tabular}

${ }_{\mathrm{Z}}^{\mathrm{T} C A}=$ trunk cross-sectional area.

Ns,*,**,**** Nonsignificant or significant at $P<0.05,0.01$, or 0.001 , respectively.

Table 8. Cumulative marketable yield, yield efficiency, tree survival, and mean rank of 10 peach seedling rootstocks.

\begin{tabular}{lcccr}
\hline \hline & $\begin{array}{c}\text { Marketable } \\
\text { yield }^{z} \\
\left(\mathrm{t} \cdot \mathrm{ha}^{-1}\right)\end{array}$ & $\begin{array}{c}\text { Yield } \\
\text { efficiency } \\
\left(\mathrm{kg} \cdot \mathrm{cm}^{-2}\right)\end{array}$ & $\begin{array}{c}\text { Tree } \\
\text { survival }^{\mathrm{x}} \\
(\%)\end{array}$ & $\begin{array}{r}\text { Mean } \\
\text { rank }^{\mathrm{w}}\end{array}$ \\
\hline Bailey & 100.1 & 1.95 & 67 & 3.0 \\
Chui Lum Tao & 132.0 & 2.22 & 83 & 1.0 \\
Halford & 117.3 & 1.31 & 17 & 10.0 \\
Harrow Blood & 98.1 & 1.92 & 50 & 7.5 \\
Lovell & 108.6 & 2.26 & 17 & 4.5 \\
Siberian C & 97.6 & 3.27 & 50 & 6.0 \\
Tzim Pee Tao & 106.1 & 1.83 & 50 & 7.5 \\
H7338013 & 114.7 & 1.86 & 83 & 2.0 \\
H7338016 & 96.6 & 1.57 & 83 & 9.0 \\
H7338019 & 113.3 & 1.59 & 67 & 4.5
\end{tabular}

$\overline{{ }^{\mathrm{z}} \text { Cumulative (1984 to 1991) yield estimated from individual tree yields } \times}$ 278 trees/ha for first 8 years of cropping.

${ }^{\mathrm{y}}$ Cumulative yield efficiency $=$ cumulative marketable yield/tree (1984 to 1991)/trunk cross sectional area (1991).

${ }^{\mathrm{x}}$ Cumulative tree survival from first (1982) to tenth (1991) year of growth. ${ }^{\mathrm{w}}$ Obtained from the evenly weighted combined ranks by rootstock for marketable yield, yield efficiency, and tree survival.

Correlation coefficients were calculated for growth and yield variables. Bloom ratings were positively correlated with fruit set and total yield (Table 7). Fruit set was positively correlated with total yield and large yield but negatively correlated with TCA. Total yield was positively correlated with large fruit, TCA, and yield efficiency. Large-fruit yield was positively correlated with fruit set, TCA, and yield efficiency.

Cumulative yield, yield efficiency, and survival. Among the experimental rootstocks ('Chui Lum Tao', 'Tzim Pee Tao', H7338013, H7338016, and H7338019), 'Chui Lum Tao' had the highest cumulative marketable yield. 'Chui Lum Tao' yields also exceeded those on each of the five commercial standards ('Bailey', 'Halford', 'Harrow Blood', 'Lovell', and 'Siberian C') (Table 8). H7338013 was the next highest yielding of the experimental rootstocks and outyielded each of the commercial standards except
'Halford'. H7338019 was the third highest yielding of the experimental stocks and outyielded four of the five commercial standards. 'Tzim Pee Tao' was the fourth highest yielding of the experimental rootstocks and outyielded three of the five commercial standards. H7338016 was the lowest yielding of the experimental rootstocks and was similar to 'Siberian C', the lowest yielding of the commercial standards.

'Chui Lum Tao' had the highest yield efficiency of the experimental rootstocks and, compared with the commercial standards, was inferior to 'Siberian C', similar to 'Lovell', but superior to the other three. H7338013 had the second highest yield efficiency among the experimental rootstocks and, compared with the commercial standards, was superior to 'Halford' and inferior to the others.

Three experimental rootstocks ('Chui Lum Tao', H7338013, and H7338016) had the highest tree survival (83\%) of all 10 rootstocks. One experimental rootstock (H7338019) survived as well as 'Bailey' among the commercial standards (67\%) and was superior to the other four standards. 'Tzim Pee Tao' had the lowest survival of the experimental rootstocks (50\%). Compared with the commercial standards, 'Tzim Pee Tao' was superior in survival to 'Halford' and 'Lovell', equal to 'Harrow Blood' and 'Siberian C', and inferior to 'Bailey'. 'Halford' and 'Lovell' had the lowest survival $(17 \%)$ of the 10 rootstocks.

The combined rank by rootstock for cumulative marketable yield, yield efficiency, and tree survival indicated that 'Chui Lum Tao' and H7338013 ranked first and second and exceeded all five of the commercial standards. 'Bailey' ranked third, while H7338019 and 'Lovell' were next and of equal rank. 'Siberian C' was next in rank, followed by 'Tzim Pee Tao' and 'Harrow Blood', which were of equal rank. H7338016 was next in rank, while 'Halford' had the lowest rank of the 10 rootstocks.

\section{Discussion}

Natural winter injury and cold hardiness of 'Redhaven' preconditioned shoots (Tables 2 and 3) were significantly affected by rootstock in some years but not in others. Similar findings have been previously reported (Durner, 1990; Durner and Rooney, 1988; Layne 1987b, 1992). These rootstock effects were often small and not always detectable. Flower bud hardiness was closely correlated with shoot xylem hardiness $(r=0.67, P<0.001)$ when considered over all rootstocks and all years (Table 6); thus, as bud hardiness increased, so did shoot xylem hardiness.

Winter injury and canker (Leucostoma spp.) are the major causes of short orchard life of peaches in Ontario, each acting as a predisposing agent for the other (Layne, 1984). These two variables were closely correlated $(r=0.71, P<0.001)$ in this study (Table 6), a result indicating that increased winter injury was accompanied by increased canker severity. By the ninth year, canker was most severe on 'Lovell'; least severe but similar on 'Chui Lum Tao', 'Halford', 'Tzim Pee Tao', and H7338013; and intermediate but similar on the other rootstocks.

Defoliation rate was consistently and significantly affected by rootstock, occurring fastest on 'Siberian C' and slowest on 'Harrow Blood' and 'Halford'. In previous experiments reviewed by Layne (1987b), the early defoliation (high defoliation rating) promoted by 'Siberian C' was associated with enhanced scion hardiness in fall and winter compared with other peach seedling rootstocks. Here we found that late defoliation (low defoliation rating) was negatively correlated with bud hardiness $(r=-0.56, P$ $<0.001)$ and winter injury $(r=-0.42, P<0.001)$. Thus, it seems that rootstocks that induce late defoliation may reduce scion bud 


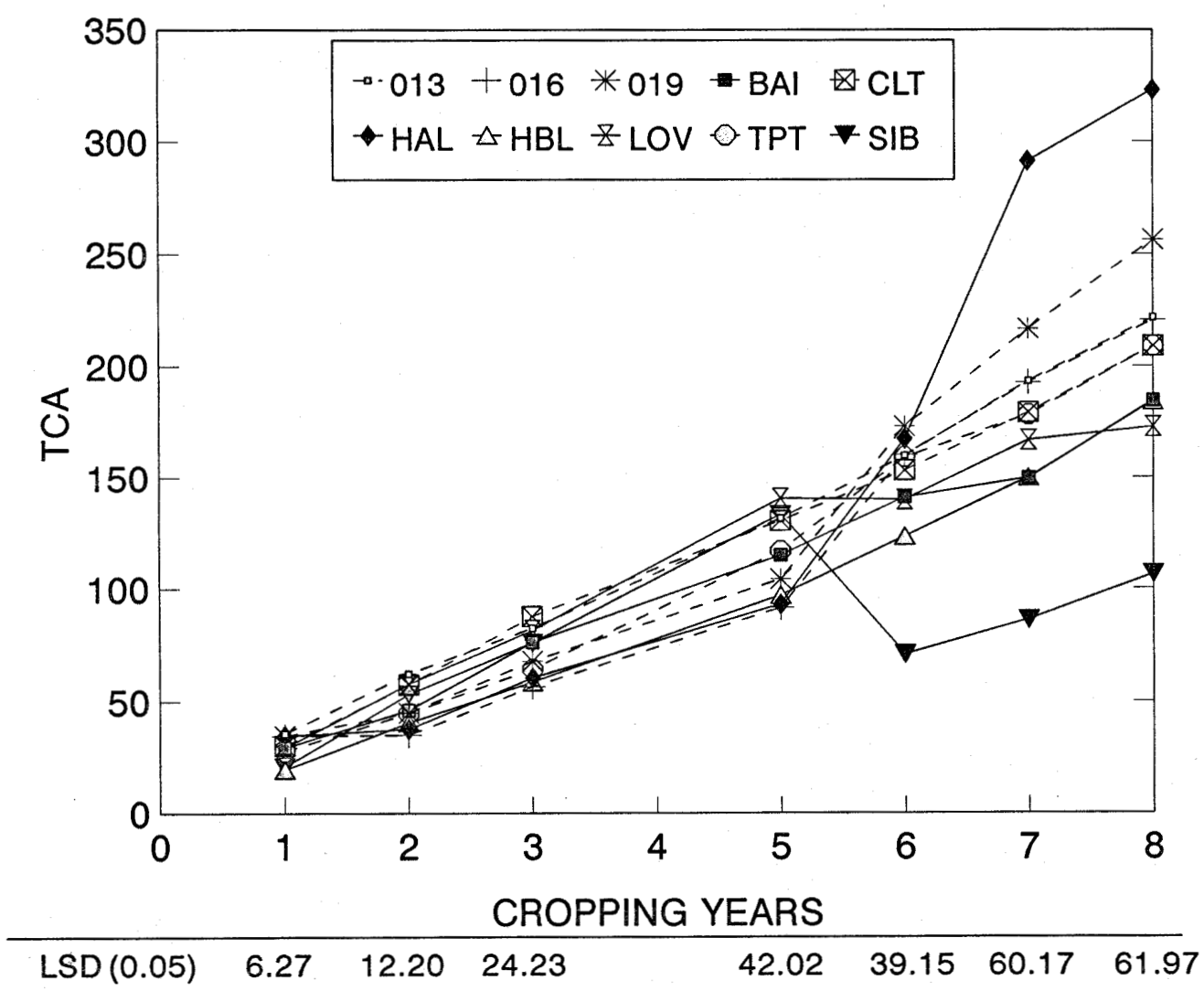

Fig. 4. Rootstock influence on trunk cross-sectional area (TCA) of 'Redhaven' peach from first (1982) to tenth (1991) year of growth. $013=\mathrm{H} 7338013,016=\mathrm{H} 7338016$, $019=$ H7338019, BAI = 'Bailey', CLT = 'Chui Lum Tao', HAL = 'Halford', HBL = 'Harrow Blood', LOV = 'Lovell', TPT = 'Tzim Pee Tao', SIB = 'Siberian C'.

hardiness and, conversely, rootstocks that induce early scion defoliation enhance scion bud hardiness.

Layne et al. (1976) reported that 'Siberian C' induced more scion dwarfing than other peach seedling rootstocks, while 'Halford' promoted increased scion vigor. Here we also found that peach seedling rootstocks significantly affected scion growth rate (Fig. 4) and final tree size (Table 4), with the largest trees on 'Halford' and the smallest on 'Siberian C'. In fact, trees on 'Siberian C' by the tenth year had not yet filled their allotted space $\left(36 \mathrm{~m}^{2}\right)$ and could have been planted closer together. Small trees are less expensive to prune, spray, and harvest than large trees (Layne, 1987b). Although trees on 'Siberian C' were the smallest, they also had the highest yield efficiency (Table 8). Had they been planted at 536 trees/ha (Layne et al., 1981), per-hectare yields would likely have been much higher than obtained here, where the tree density was much lower ( 278 trees/ha).

As expected, bloom, fruit set, and yield were significantly and positively correlated regardless of rootstock (Table 7), because these variables are biologically related. There was an even closer relationship between TCA and yield, because TCA is a good indirect measure of fruit-bearing surface and is correlated with yield (Layne et al., 1976; Westwood et al., 1963). Although the rootstocks differed in bloom and fruit set ratings, the rootstock effect on yield was not strongly expressed. Yield may be controlled by so many physiological, environmental, and management factors that counteract each other that the rootstock effect would have less chance to be demonstrated. Nevertheless, 'Chui Lum Tao' consistently was associated with the heaviest bloom, highest fruit set, and greatest yield of the 10 rootstocks.

Total yield and marketable yield were affected to a much greater extent by differences in tree size and differences among years than by rootstock effects (Table 5) and there was no significant rootstock $\times$ year interaction. Nevertheless, 'Chui Lum Tao' had the highest total and marketable yields and 'Harrow Blood' had the lowest. The yield of large fruit was closely correlated with total yield, TCA, and yield efficiency when considered over all rootstocks and years (Table 7).

Originally, each rootstock treatment was represented by six trees. Tree numbers declined with tree age, regardless of rootstock, but declined the most in the last 2 years. Estimates of total and marketable yields (Figs. 1 and 2) were based on the yields of surviving trees. Such yields would tend to be overestimated or underestimated depending on the size and health of surviving trees. Thus, 'Halford' yields were likely overestimated in the seventh and eight years (Figs. 3 and 4) because they were based on two and one surviving tree, respectively, and because these trees were large (Fig. 4) and relatively healthy. By contrast, the yields on 'Siberian C' (Figs. 1 and 2) were likely underestimated, because the three surviving trees in the sixth, seventh, and eighth years were the smallest (Fig. 4) and were relatively unhealthy. The sharp decline noted in TCA from the fifth to the sixth and subsequent years for 'Siberian C' (Fig. 4) was because the three trees that survived to the eighth cropping year were smaller than those that died by the sixth cropping year and, therefore, tree size was underestimated.

Cumulative tree survival to the tenth year is an important factor to assess rootstock adaptation to a given soil type and climatic zone. Low survival (17\%) associated with 'Halford' and 'Lovell' (Table 8) was indicative of inadequate adaptation for very light, sandy soils in southern Ontario, despite satisfactory survival on heavier soils in Ontario (Layne, 1994) and in regions farther south 
(Dozier et al., 1984; Yadava and Doud, 1980). These rootstock seed sources originated in California and were not selected for cold hardiness or canker tolerance, the major causes of tree death in Ontario (Layne, 1984). In contrast, rootstock seed sources selected in southern Ontario, Iowa, and northern China were associated with better scion survival, because they were more cold hardy than those from California (Layne, 1987b). Two Harrow hybrids (H7338013 and H7338016) were comparable with 'Chui Lum Tao' in promoting the highest tree survival (83\%) of the 10 rootstocks (Table 8 ). These hybrids promoted higher survival than either parent ('Bailey' and 'Siberian C)' for which respective tree survival was $67 \%$ and $50 \%$. The other Harrow hybrid (H7338019) equalled one of its parents ('Bailey') and surpassed the other ('Siberian C') in tree survival.

When tree survival, cumulative marketable yields, and yield efficiency were equally weighted and considered together (Table 8), 'Chui Lum Tao' and H7338013 ranked first and second, respectively, of the 10 rootstocks studied. Therefore, they were considered to have the highest commercial potential of the 10 rootstocks studied for the light, sandy soils of southern Ontario. 'Chui Lum Tao' is now being recommended for commercial use (Layne, 1989b), and H7338013 is being considered for commercial introduction. 'Bailey' performed best of the five commercial standards and also exceeded three of the experimental rootstocks; thus, 'Bailey' warrants continued use in northern areas (Elfving and Tehrani, 1984). Neither 'Halford' nor 'Lovell' were well enough adapted, as indicated by low tree survival, to warrant continued use on light sandy soils in southern Ontario. 'Siberian C' promoted adequate tree survival (Table 8) and induced more scion dwarfing (Table 4) than the other rootstocks. However, trees on this rootstock would require closer spacing than the one used in this experiment to take advantage of its high yield efficiency. 'Harrow Blood' and 'Tzim Pee Tao' did not perform as well as 'Siberian C' and seem to have more limited commercial potential for southern Ontario. Among the three experimental hybrids (H7338013, H7338016, and H7338019) compared with their parents ('Bailey' and 'Siberian C'), H7338013 surpassed the overall performance of its parents, H7338019 surpassed 'Siberian C' but not 'Bailey', and H7338016 was inferior to both parents. These hybrids require wider testing to assess their performance in other soil types and climatic zones.

\section{Literature Cited}

Beckman, T. and J.N. Cummins. 1992. Rootstock for peaches, p. 974. In: J.N. Cummins (ed.). Register of new fruit and nut varieties Brooks and Olmo List 35. HortScience 26:951-986.

Dozier, Jr., W.A., J.W. Knowles, C.C. Carlton, R.C. Rom, E.H. Arrington,
E.J. Wehunt, U.L. Yadava, S.L. Doud, D.F. Ritchie, C.N. Clayton, E.I. Zehr, C.E. Gambrell, J.A. Britton, and D.W. Lockwood. 1984. Survival, growth, and yield of peach trees affected by rootstocks. HortScience 19:26-30.

Durner, E.F. 1990. Rootstock influence on flower bud hardiness and yield of 'Redhaven' peach. HortScience 25:172-173.

Durner, E.F. and F.X. Rooney. 1988. 'Rio Oso Gem' and 'Loring' peach flower bud and wood hardiness as affected by different rootstocks. Fruit Var. J. 42:134-138.

Elfving, D.C. and G.Tehrani. 1984. Rootstocks for fruit trees. Ontario Ministry Agr. and Food. Publ. 334.

Layne, R.E.C. 1984. Breeding peaches in North America for cold hardiness and perennial canker (Leucostoma spp.) resistance-Review and outlook. Fruit Var. J. 36:90-98.

Layne, R.E.C. 1987a. Update on peach rootstock research. Compact Fruit Tree 20:139-142.

Layne, R.E.C. 1987b. Peach rootstocks, p. 185-216. In: R.C. Rom and R.F. Carlson (eds.). Rootstocks for fruit crops. Wiley, New York.

Layne, R.E.C. 1989a. Effect of Prunus rootstocks on orchard performance of 'Redhaven' peach. HortScience 24:99. (Abstr.)

Layne, R.E.C. 1989b. CLT and TPT, two hardy rootstock seed sources for peach. WOFTA News 20(3):5.

Layne, R.E.C. 1989c. Breeding cold hardy peaches for Canada. Acta Hort. 254:73-78.

Layne, R.E.C. 1992. Breeding cold hardy peaches and nectarines. In: J. Janick (ed.). Plant Breeding Reviews p. 271-306. vol 10. Wiley, New York.

Layne, R.E.C. 1994. Prunus rootstocks affect long-term orchard performance of 'Redhaven' peach on Brookston clay loam. HortScience 29:167-171.

Layne, R.E.C., C.S. Tan, and J.M. Fulton. 1981. Effect of irrigation and tree density on peach production. J. Amer. Soc. Hort. Sci. 106:151-156.

Layne, R.E.C., C.S. Tan, and R.L. Perry. 1986. Characterization of peach rootstocks in Fox sand as influenced by sprinkler irrigation and tree density. J. Amer. Soc. Hort. Sci. 111:670-677.

Layne, R.E.C., G.M. Weaver, H.O. Jackson, and F.D. Stroud. 1976. Influence of peach seedling rootstocks on growth, yield and survival of peach scion cultivars. J. Amer. Soc. Hort. Sci. 101:568-572.

Ontario Ministry of Agriculture and Food. 1991. 1992-1993 Fruit production recommendations. Ontario Ministry of Agr. and Foods. Publ. 360.

Potter, R.W., V.A. Dirks, P.W. Johnson, T.H.A. Olthof, R.E.C. Layne, and M.M. McDonnell. 1984. Response of peach seedlings to infection by the root lesion nematode, Pratylenchus penetrans under controlled conditions. J. Nematol. 16:317-322.

Rom, R.C. 1983. The peach rootstock situation: An international perspective. Fruit Var. J. 37:3-14.

Westwood, M.N., F.C. Reimer, and V.L. Quackenbush. 1963. Long term yield as related to ultimate tree size of three pear varieties grown on rootstocks of five Pyrus species. Proc. Amer. Soc. Hort. Sci. 82:103108.

Yadava, V.L., and S.L. Doud. 1980. The short life and replant problem of deciduous fruit trees. p. 1-116. In: J. Janick (ed.). Horticultural reviews. vol. 2. AVI Publishing Co., Westport, Conn. 